\title{
Sheathless High-Throughput Circulating Tumor Cell Separation Using Viscoelastic non-Newtonian Fluid
}

\author{
Hyunjung Lim ${ }^{1}$, Seung Min Back ${ }^{1}$, Min Ho Hwang ${ }^{1}$, Dae-Hee Lee ${ }^{2,3}$, Hyuk Choi ${ }^{1, *}$ \\ and Jeonghun Nam ${ }^{4,5, *}$ \\ 1 Department of Medical Sciences, Graduate School of Medicine, Korea University, Seoul 02841, Korea \\ 2 Graduate School of Medicine, Korea University College of Medicine, Seoul 02841, Korea \\ Department of Oncology, Korea University Guro Hospital, Seoul 08308, Korea \\ 4 Department of Laboratory Medicine, College of Medicine, Korea University Guro Hospital, \\ Korea University, Seoul 08308, Korea \\ 5 Department of Emergency Medicine, College of Medicine, Korea University Guro Hospital, \\ Korea University, Seoul 08308, Korea \\ * Correspondence: hyuk76@korea.ac.kr (H.C.); jhnam77@gmail.com (J.N.); \\ Tel.: +82-2-2626-3302 (H.C.); +82-2-2626-2422 (J.N.)
}

Received: 15 June 2019; Accepted: 9 July 2019; Published: 10 July 2019 updates

\begin{abstract}
Circulating tumor cells (CTCs) have attracted increasing attention as important biomarkers for clinical and biological applications. Several microfluidic approaches have been demonstrated to separate CTCs using immunoaffinity or size difference from other blood cells. This study demonstrates a sheathless, high-throughput separation of CTCs from white blood cells (WBCs) using a viscoelastic fluid. To determine the fluid viscoelasticity and the flow rate for CTC separation, and to validate the device performance, flow characteristics of 6,13 , and $27 \mu \mathrm{m}$ particles in viscoelastic fluids with various concentrations were estimated at different flow rates. Using $0.2 \%$ hyaluronic acid (HA) solution, MCF-7 (Michigan Cancer Foundation-7) cells mimicking CTCs in this study were successfully separated from WBCs at $500 \mu \mathrm{L} / \mathrm{min}$ with a separation efficiency of $94.8 \%$. Small amounts of MCF-7 cells $(\sim 5.2 \%)$ were found at the center outlet due to the size overlap with WBCs.
\end{abstract}

Keywords: circulating tumor cell; white blood cell; sheathless; high-throughput; viscoelastic fluid; separation

\section{Introduction}

Circulating tumor cells (CTCs) are defined as rare tumor cells within the peripheral bloodstream. They are shed from the primary tumor, and can be a vital cause of hematogenous metastases $[1,2]$. Recently, CTCs have attracted increasing attention as they contain important information regarding cancer and its metastasis. CTCs can also be used as non-invasive biomarkers for early diagnosis, real-time monitoring of therapeutic processes, and genotypic and phenotypic changes in research applications [3,4]. However, due to their extreme rarity (1-10 CTCs per milliliter blood) and heterogeneity [5], it is difficult to distinguish CTCs amongst billions of red blood cells (RBCs) and millions of white blood cells (WBCs).

Recent advancements in microfluidics enable the utilization of microfluidic techniques for cell separation from a heterogeneous mixture sample [6,7]. Most current approaches for CTC separation employ affinity-based capture methods using an antibody that targets the tumor cell surface antigens, such as epithelial cell adhesion markers (EpCAM) [8]. However, due to the epithelial-to-mesenchymal transition (EMT), which may cause downregulation of epithelial surface markers, the capture efficiency can be limited [9]. To address the limitation of immuno-separation methods, size distinction of CTCs 
from other blood cells has been used as an alternative biophysical marker, negating the use of labeling. Microfluidic size-based separation techniques can be divided into two categories, active and passive, depending on the use of external forces. Active techniques employ external force fields, including dielectric $[10,11]$ and acoustic fields [12-15], to separate CTCs, while passive methods utilize a special channel design, such as mechanical filtering techniques using microsieves [16,17], weir [18] and pillar arrays [19], deterministic lateral displacements (DLD) [20], dean flow fractionation (DFF) [21,22], and microfluidic vortices [23,24]. Active techniques for CTC separation have limited throughput due to the working time required for samples to be affected by external force fields ( $20 \mu \mathrm{L} / \mathrm{min}[11]$ and $\sim 80 \mu \mathrm{L} / \mathrm{min}$ [13]). Passive methods require no external force fields and can achieve relatively high throughput ( $\sim 10 \mathrm{~mL} / \mathrm{min}$ [20] and $\sim 3 \mathrm{~mL} / \mathrm{min}$ [17]), however, elaborate channel structures or complex fabrication processes for three-dimensional structures are required.

Recently, viscoelastic non-Newtonian microfluidics has gained heightened attention due to the intrinsic properties of viscoelastic fluids, which allow for easier manipulation of cells without the need for complex channel structures [25]. In addition, compared to previous passive methods, viscoelastic cell separation can be achieved over a wide working range of flow rates simply by modulating the viscoelastic fluid rheological properties. In a non-Newtonian fluid, non-uniform distribution of the first normal stress difference $\left(N_{1}\right)$ can drive suspended cells laterally in a simple straight microchannel, which has been applied to particle/cell focusing [26-29] and size-based particle/cell separation [30-35]. More recently, size-based separation techniques using viscoelastic fluid flows have been applied to separate CTCs from other blood cells $[33,36,37]$. However, the throughputs of these approaches $(\sim 7.5 \mu \mathrm{L} / \mathrm{min}[36]$ and $\sim 50 \mu \mathrm{L} / \mathrm{min}$ [37]) were lower than previous reports on CTC separation $(\sim 80 \mu \mathrm{L} / \mathrm{min}$ [13], $\sim 200 \mu \mathrm{L} / \mathrm{min}$ [12], and $\sim 280 \mu \mathrm{L} / \mathrm{min}$ [38]), which can limit the separation of extremely rare CTC separation. Also, complicated channel geometry was required for high separation efficiency [33].

In this study, we show the sheathless, high-throughput separation of CTCs using a viscoelastic fluid in a low aspect ratio (AR = height/width) microchannel. Size-dependent equilibrium positions in a straight rectangular microchannel with a low AR have previously been examined using a viscoelastic fluid [37-39]. However, to the best of the authors' knowledge, previous studies have not used a low AR microfluidic device for continuous separation of CTCs from lysed blood samples. We examined the equilibrium positions of particles with different sizes depending on the viscoelastic fluid rheological properties and flow rates. Finally, optimized flow characteristics with a specific flow rate and concentration of a viscoelastic fluid were adopted to separate CTCs. Based on the results provided in this work, our device provides a simple but powerful tool for high-throughput separation of extremely rare, heterogeneous CTCs.

\section{Working Principle}

A schematic of the proposed device for sheathless high-throughput CTC separation using a viscoelastic non-Newtonian fluid is shown in Figure 1. As shown in the schematic, the device consists of a microfluidic channel with a low aspect ratio of 0.5 . The initial sample mixture contains large tumor cells and relatively smaller WBCs suspended in a viscoelastic fluid with low viscosity but high elasticity [40]. This can enhance the throughput of the proposed device. At the inlet, the cells were injected as randomly distributed, as shown in the cross-sectional view in Figure 1. 


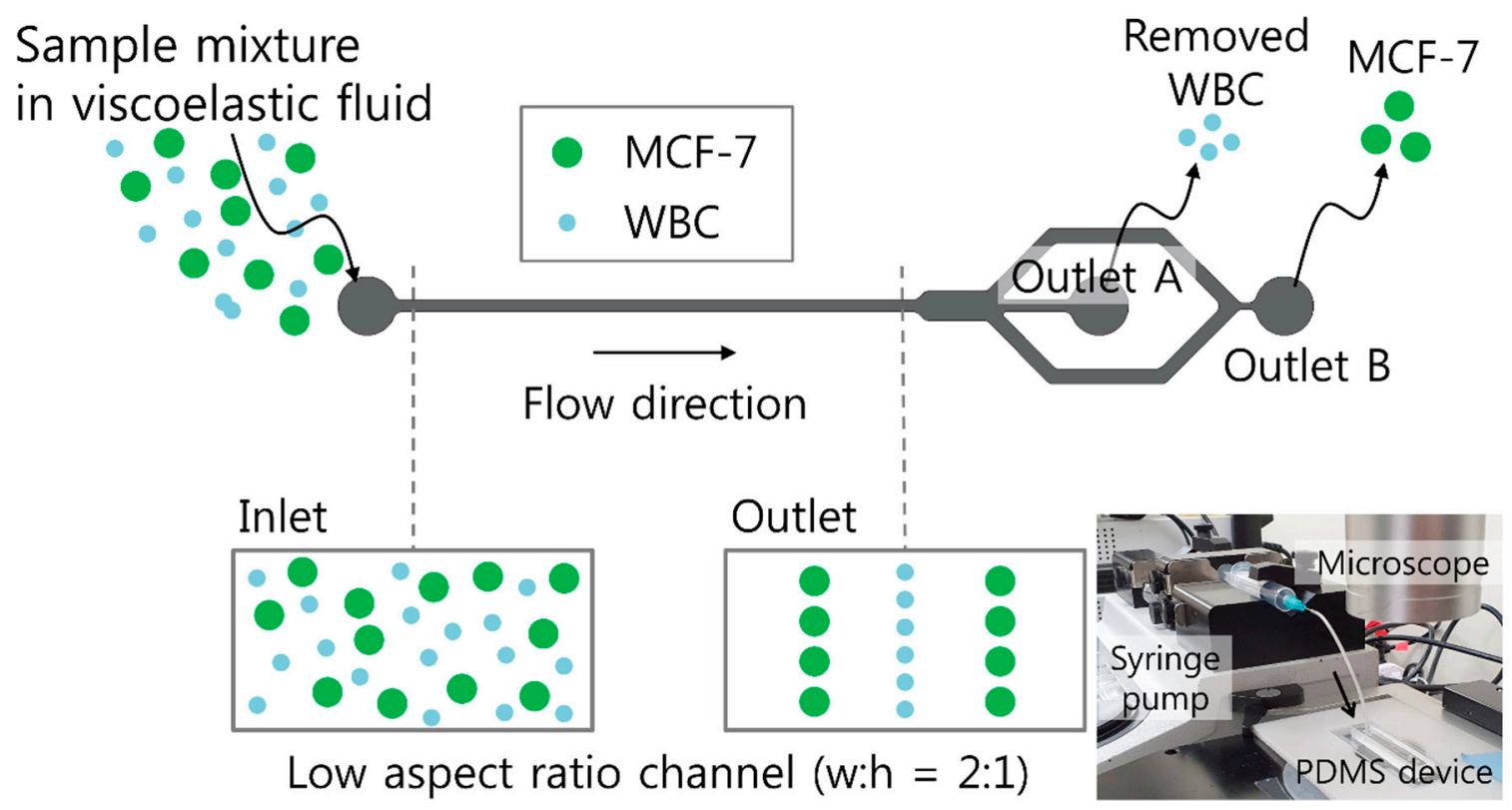

Figure 1. Schematic of sheathless, high-throughput separation of circulating tumor cells using a viscoelastic non-Newtonian fluid. Sample mixtures containing MCF-7 (Michigan Cancer Foundation-7) cells and white blood cells (WBCs) in a viscoelastic fluid were randomly introduced to the inlet of a low aspect ratio microchannel. Due to size-dependent viscoelastic separation, MCF-7 cells were separated at the rear outlet, while WBCs were removed at the center outlet. Inset (bottom right) shows an experimental setup consisting of a syringe pump, a microscope, and the polydimethylsiloxane (PDMS) channel device.

During the flow of the viscoelastic fluid, the elastic force $\left(F_{e}\right)$ is induced by non-uniform differences in the first normal stress $\left(N_{1}\right)$, which depends on the cell size [41,42].

$$
F_{e} \sim a^{3} \frac{\partial N_{1}}{\partial x} \sim \lambda(a / W)^{3} Q^{3}
$$

Here, $a, N_{1}, x, W$, and $Q$ are the cell diameter, first normal stress difference, lateral distance, width of the microchannel, and volumetric flow rate, respectively. The inertial lift force also affects the lateral migration of cells in a viscoelastic fluid, which can be divided into two counteracting components, namely, the shear gradient lift force $\left(F_{i, s}\right)$ and the wall repulsion force $\left(F_{i, w}\right)$.

$$
F_{i}=F_{i, s}+F_{i, w} \sim \rho(a / W)^{4} Q^{2}
$$

Here, $\rho$ is the solution density. The elastic force drives the suspended cells to low shear rate regions at the center and four corners of the microchannel. Conversely, the shear-gradient lift force drives the cells toward the channel walls, while the wall repulsion force drives cells to the center of the channel.

Both elastic and inertial forces affecting the suspended cells are dependent on the cell diameter, $a$, but elastic and inertial force scale differently with the cell diameter. The cells with different sizes therefore migrate toward distinct equilibrium positions in the microchannel, which enables size-based cell separation [38,39]. Briefly, the MCF-7 (Michigan Cancer Foundation-7) cells with a high blockage ratio $(\beta=a / H ; H$ indicates the channel height) are affected by the elastic force, driving the cells toward the channel walls. However, when considering small cells in comparison to the channel size (WBCs), inertial lift force affects the cells driving away from the channel walls and the center, while the elastic force drives the cells to the channel center. The diameters of WBCs and MCF-7 cells are known to be 9-15 $\mu \mathrm{m}$ and 14-27 $\mu \mathrm{m}$, respectively [22,39]. To apply the working principle of our device for MCF-7 cell separation from WBCs, a straight microchannel with $100 \mu \mathrm{m}$ width, $50 \mu \mathrm{m}$ height, and $25 \mathrm{~mm}$ 
length was designed. Therefore, the blockage ratios $(\beta)$ of WBCs and MCF-7 cells could be calculated as $0.18-0.3$ and $0.28-0.54$, respectively. As shown in the cross-sectional view at the outlet in Figure 1 , WBCs are tightly focused at the center of the microchannel, while MCF-7 cells are located at two equilibrium positions between the center and the side walls of the microchannel. WBCs are removed from the initial mixture at the center outlet (Outlet A), while MCF-7 cells can be collected at the rear outlet (Outlet B). The inset figure at the bottom right shows the experimental setup of a syringe pump for sample injection, a microscope for optical observation, and the polydimethylsiloxane (PDMS) channel device with a single inlet and two outlets.

To characterize the fluid and the cell dynamics during the viscoelastic flow, non-dimensional numbers should be considered. The Reynolds number $(R e)$ describes the ratio of the inertial force to the viscous force, $R e=\frac{\rho V_{m} D_{h}}{\eta_{c}}$, whereas the Weissenberg number $(W i)$ describes the ratio of the elastic force to the viscous force, $W i=\lambda \dot{\gamma}_{c}$. Here, $\rho, V_{m}, D_{h}, \eta_{c}, \lambda$, and $\dot{\gamma}_{c}$ indicate the solution density, mean flow velocity, hydraulic diameter of the particle, characteristic viscosity of the solution, fluid relaxation time, and characteristic shear rate, respectively. The relative effect of fluid elasticity to inertia is evaluated by the elasticity number, $E l=W i / R e$.

\section{Materials and Methods}

\subsection{Device Design and Fabrication}

A straight microfluidic channel of $100 \mu \mathrm{m}$ width and $50 \mu \mathrm{m}$ height was used, and thus the aspect ratio was defined as $1 / 2$ ( $\mathrm{AR}=$ height/width). The length of the main channel was $25 \mathrm{~mm}$ and the width of the expansion region at the outlet trifurcation was $800 \mu \mathrm{m}$ for visualization of the flow streams of particles and cells. At the entrance region of the microchannel, micropillars of $50 \mu \mathrm{m}$ width and 100 $\mu \mathrm{m}$ length were designed with $50 \mu \mathrm{m}$ spacing to avoid the possible blockage of the microchannel by aggregated particles or CTC clusters. In clinical samples, CTC clusters can be found in approximately $5-20 \%$ of the total CTCs $[43,44]$.

A polydimethylsiloxane (PDMS) microfluidic channel was fabricated using standard soft-lithography techniques with a replica mold, which was fabricated using an SU-8 negative photoresist (MicroChem, Newton, MA, USA) on a silicon wafer. A 10:1 mixture of the PDMS base and curing agent (Sylgard 184, Dow Corning, Midland, MI, USA) was cast over the replica mold, degassed in a vacuum chamber, and baked in an oven at $80^{\circ} \mathrm{C}$ for $1 \mathrm{~h}$. The cured PDMS channels were peeled off from the mold and bonded on a glass slide with oxygen plasma (CUTE, Femto Science, Gyeonggi, Korea). To minimize unwanted hydrophobic interactions between polystyrene particles and the channel surface, the PDMS channel was treated with Tween 20 [45].

\subsection{Sample Preparation}

Hyaluronic acid (HA) solutions at various concentrations $(0.1,0.2$, and $0.3(w / v) \%)$ were prepared by adding hyaluronic acid (HA) sodium salt ( $357 \mathrm{kDa}$, Lifecore Biomedical, Chaska, MN, USA) powder to phosphate-buffered saline (PBS) to evaluate the effect of viscoelasticity on flow characteristics. To estimate the flow characteristics, fluorescent polystyrene particles with diameters of $6 \mu \mathrm{m}, 13 \mu \mathrm{m}$, and $27 \mu \mathrm{m}$ (ThermoFisher, Waltham, MA, USA) were used. The particle diameters of 13 and $27 \mu \mathrm{m}$ were selected as analogues to white blood cells (WBCs) and MCF-7 tumor cells, respectively. The particles were suspended in HA solution at each concentration at a final concentration of approximately $1.2 \times 10^{6}$ particles $/ \mathrm{mL}$.

A droplet of untreated human blood directly taken from a fingertip was used. The blood samples were lysed by 10x-diluted BD FACS (Fluorescence Activated Cell Sorter) lysis buffer (BD (Becton, Dickinson and Company) Biosciences, San Jose, CA, USA) and WBCs in lysed blood sample were stained using a fluorescent dye (SYBR Green).

Human breast adenocarcinoma cell line MCF-7 cells were used to mimic CTCs in this study. MCF-7 cells were maintained and propagated in DMEM (Dulbecco's Modified Eagle's Medium)/F12 
supplemented with 10\% fetal bovine serum (FBS, Gibco-BRL (Bethesda Research Laboratories)) and 1\% penicillin/streptomycin (P/S, Gibco-BRL). The cells were cultured in $75-\mathrm{cm}^{2}$ cell culture flasks (VWR Scientific Products, Bridgeport, NJ, USA) in a humidified atmosphere with $5 \% \mathrm{CO}_{2}$ at $37^{\circ} \mathrm{C}$ to $70-80 \%$ confluence. Final concentrations of cells were $\sim 1.2 \times 10^{5} \mathrm{MCF}-7$ cells $/ \mathrm{mL}$ and $\sim 1.8 \times 10^{5} \mathrm{WBCs} / \mathrm{mL}$, respectively. Final concentration of MCF-7 cells in the sample solution was set to be higher than that of a clinical sample for demonstration of the device performance [46].

\subsection{Fluid Rheology Measurements}

The rheological properties of HA solutions were measured by a dynamic light scattering system (Zetasizer ZSP, Malvern Instruments, Malvern, UK) using microrheology measurement at $20{ }^{\circ} \mathrm{C}$, since HA solutions are polymer solutions with low viscosity and elasticity. Based on measurement of viscoelastic moduli, G' and G", the zero-shear viscosity and the relaxation time of $0.1(w / v) \% \mathrm{HA}$ solution were measured as $0.89 \mathrm{mPa} \cdot \mathrm{s}$ and $0.25 \mathrm{~ms}$, respectively, which showed good agreement with the reported values in previous research [40]. Measured zero-shear viscosities and the relaxation times of the polymer solutions are summarized in Table 1.

Table 1. Rheological properties of the prepared polymer solutions at $20^{\circ} \mathrm{C}$.

\begin{tabular}{cccc}
\hline \multirow{2}{*}{ Properties } & \multicolumn{3}{c}{ Hyaluronic Acid (HA) Concentration (wt.\%) } \\
\cline { 2 - 4 } & $\mathbf{0 . 1}$ & $\mathbf{0 . 2}$ & $\mathbf{0 . 3}$ \\
\hline Density $\left(\mathrm{g} / \mathrm{cm}^{3}\right)$ & 1.0 & 1.0 & 1.0 \\
Zero-shear viscosity $(\mathrm{mPa} \cdot \mathrm{s})$ & 0.89 & 0.97 & 1.16 \\
Relaxation time $(\mathrm{ms})$ & 0.25 & 0.28 & 0.31 \\
\hline
\end{tabular}

\subsection{Experimental Procedure}

The flow rate of the sample solution was controlled by using a syringe pump (KDS210, KD Scientific, Holliston, MA, USA). During the experiment, particles and cells flowing in the microchannel were monitored by an inverted microscope (CKX41, Olympus, Tokyo, Japan with a high-speed camera (V611, Phantom, Wayne, NJ, USA) and a fluorescent camera (CS230B. Olympus, Tokyo, Japan).

\section{Results and Discussion}

To examine the effect of viscoelasticity on flow characteristics of 6,13 , and $27 \mu \mathrm{m}$ fluorescent particles (blockage ratios $\beta=0.12,0.26$, and 0.54 ), distributions of particles suspended in PBS, $0.1 \% \mathrm{HA}$, $0.2 \% \mathrm{HA}$, and $0.3 \% \mathrm{HA}$ solution were observed. Figure 2 shows the stacked microscopic images and normalized fluorescence intensities of each particle in the expansion region at a flow rate of $300 \mu \mathrm{L} / \mathrm{min}$. In PBS without elasticity, 6 and $13 \mu \mathrm{m}$ particles $(\beta=0.12$ and 0.26$)$ were weakly focused into three fluorescent streams at the channel center and near the side walls, while $27 \mu \mathrm{m}$ particles $(\beta=0.54)$ were tightly focused at the channel center at $300 \mu \mathrm{L} / \mathrm{min}(R e=75.1)$. This agrees with previous reports regarding inertial flow characteristics in a low AR channel [47]. In $0.1 \%$ HA solution $(R e=74.9$, $W i=5.0, E l=0.06), 6 \mu \mathrm{m}$ particles $(\beta=0.12)$ were focused along the centerline, while 13 and $27 \mu \mathrm{m}$ particles $(\beta=0.26$ and 0.54 ) were weakly focused into two fluorescent streams between the center and the side walls. For non-Newtonian fluid flow in a HA solution, the equilibrium position of particles was determined by the simultaneous effect of three main parameters: (1) flow inertia, (2) flow elasticity, and (3) the blockage ratio of each particle in the microchannel. For small particles compared to the channel size, inertial lift force drives particles away from the side walls and the center and elastic lift force drives particles to the center. Therefore, center-focusing of small particles can be achieved. When the blockage ratio of the particles is high $(\beta>0.25)$, the side wall-bound elastic lift force acts on the particles due to fluid elasticity, which shows a strong dependence on the particle size compared to the center-bound elastic force $[38,48,49]$. The particles with $\beta>0.25$ are, therefore, off-center focused. These results showed good consistency with previous studies [38,39]. 


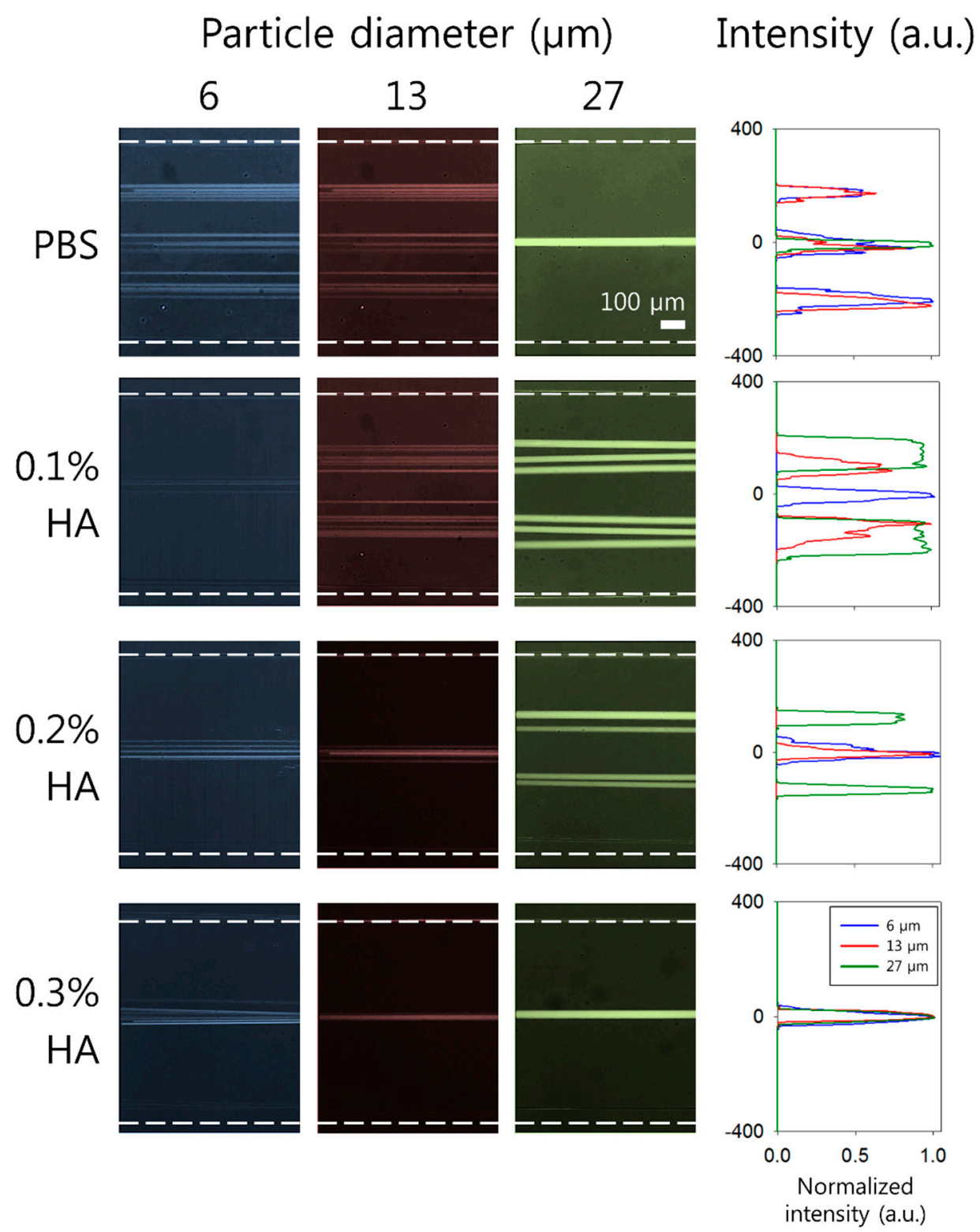

Figure 2. Effect of the polymer concentration on the particle size-dependent flow characteristics of fluorescent polystyrene particles with 6,13 , and $27 \mu \mathrm{m}$ diameters using phosphate-buffered saline (PBS), $0.1 \%, 0.2 \%$, and $0.3 \%$ HA solution. Stacked microscopic images (left) and normalized fluorescent intensities (right) in an expansion region at the fixed flow rate of $300 \mu \mathrm{L} / \mathrm{min}$. White dotted lines indicate the channel sidewalls.

With an increased concentration of the HA solution to $0.2(R e=68.7, W i=5.6, E l=0.08)$ and $0.3 \%$ $(R e=57.5, W i=6.2, E l=0.10), W i$ increases and $R e$ decreases due to the increased relaxation time and viscosity, leading to increased $\mathrm{El}$. As the elasticity is enhanced in $0.2 \% \mathrm{HA}$ solution, the focusing positions of the particles ( 6 and $13 \mu \mathrm{m}$ ) were shifted to the center of the channel, while $27 \mu \mathrm{m}$ particles were still focused into two streams at the equilibrium positions. In $0.3 \%$ HA solution, all particles $(6,13$, and $27 \mu \mathrm{m})$ were tightly focused at the center of the channel. Flow patterns of $27 \mu \mathrm{m}$ particles in PBS and $0.3 \%$ HA solution seemed to be identical, however, flow characteristics induced by inertial effect (PBS) and elastic effect ( $0.3 \%$ HA solution) were different, which can be seen in Figure S1.

Flow rate-dependent fluorescent particle distributions in the expansion region were examined at different flow rates of 100,300 , and $500 \mu \mathrm{L} / \mathrm{min}$ using $13 \mu \mathrm{m}(\beta=0.26)$ and $27 \mu \mathrm{m}(\beta=0.54)$ particles in $0.2 \%$ HA solution. Figure 3 shows normalized fluorescence intensities in the expansion region of 
13 and $27 \mu \mathrm{m}$ particles during the flow at 100, 300, and $500 \mu \mathrm{L} / \mathrm{min}$, respectively. As the flow rate increases from $100 \mu \mathrm{L} / \mathrm{min}$ to $500 \mu \mathrm{L} / \mathrm{min}$, the values of non-dimensional numbers (Re and Wi) increases, which results in a large elastic force. The focusing position of $13 \mu \mathrm{m}$ particles remains identical over flow rates ranging from $100 \mu \mathrm{L} / \mathrm{min}(R e=22.9, W i=1.87, E l=0.08)$ to $500 \mu \mathrm{L} / \mathrm{min}(R e=114.5$, $W i=9.3, E l=0.08)$. Meanwhile, $27 \mu \mathrm{m}$ particles that were focused near the center of the channel at $100 \mu \mathrm{L} / \mathrm{min}$ showed an outward migration into two separate streams as the flow rate increased to 300 and $500 \mu \mathrm{L} / \mathrm{min}$. This shift of equilibrium positions may be explained by the strong dependence of side wall-bound elastic force on the flow rate and particle size. Based on this trend of 13 and $27 \mu \mathrm{m}$ particles suspended in $0.2 \%$ HA solution, our device can be applied to sheathless, label-free separation of cells.

\section{Particle diameter ( $\mu \mathrm{m})$ Intensity (a.u.)}

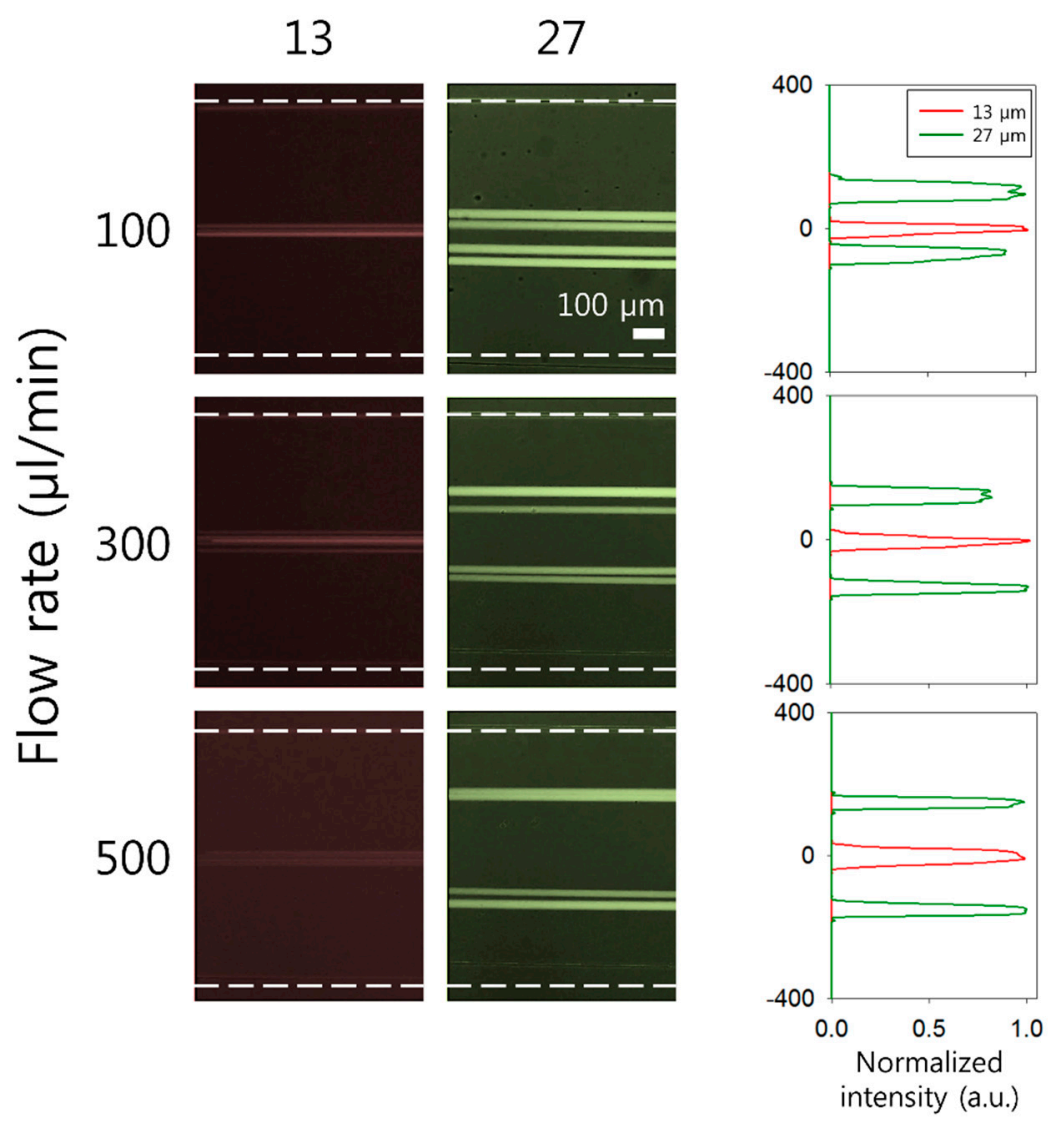

Figure 3. Effect of the flow rate on the particle size-dependent flow characteristics of fluorescent polystyrene particles with 13 and $27 \mu \mathrm{m}$ diameters at the flow rates of 100, 300, and $500 \mu \mathrm{L} / \mathrm{min}$. Stacked microscopic images (left) and normalized fluorescent intensities (right) of particles in an expansion region suspended in $0.2 \%$ HA solution. White dotted lines indicate the channel sidewalls.

To evaluate the applicability of the device for clinical application of detecting CTCs in lysed blood samples, the separation of MCF-7 cells from WBCs was performed using optimized experimental conditions. The concentration of polymer solution $(0.2 \%$ HA solution) and the flow rate $(500 \mu \mathrm{L} / \mathrm{min})$ were determined based on the results in Figure 3. Figure 4a,b shows the stacked microscopic images at the inlet and outlet of the microchannel during the separation process, which was recorded with a high-speed camera. A binary mixture containing both cells (MCF-7 cells and WBCs) was injected at the inlet without sheath fluids and the cells were randomly distributed in the microchannel, as shown in Figure 4a. At the outlet, MCF-7 cells and WBCs were separated into different streamlines, which flowed to different outlets (Figure 4b) (see supplementary video Movie S1). WBCs were tightly focused 
at the center of the channel due to their relatively small size (mean $\pm \mathrm{SD}=11.0 \pm 5.0, \mathrm{SD}$ is standard deviation, $0.12 \leqq \beta \leqq 0.32$ ), while MCF-7 cells (mean $\pm \mathrm{SD}=23.1 \pm 3.9,0.38 \leqq \beta \leqq 0.54$ ) migrated to two equilibrium positions between the channel center and the side walls, which shows good agreement with the flow characteristics of particles shown in Figure 2 and 3. Size distribution of both MCF-7 cells and WBCs can be found in Figure S2.

(a) Inlet

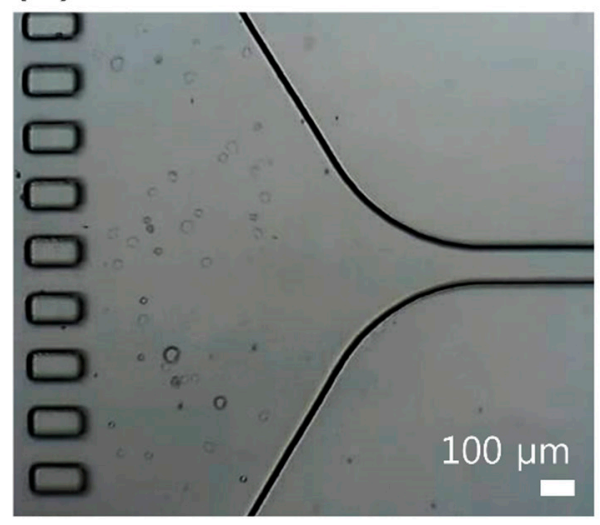

(c) WBC

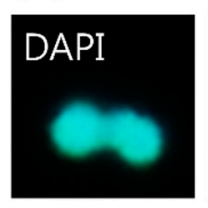

(e)
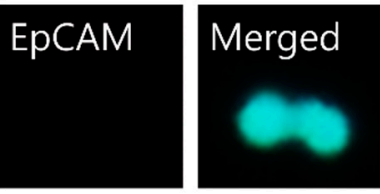

\section{(b) Outlet}

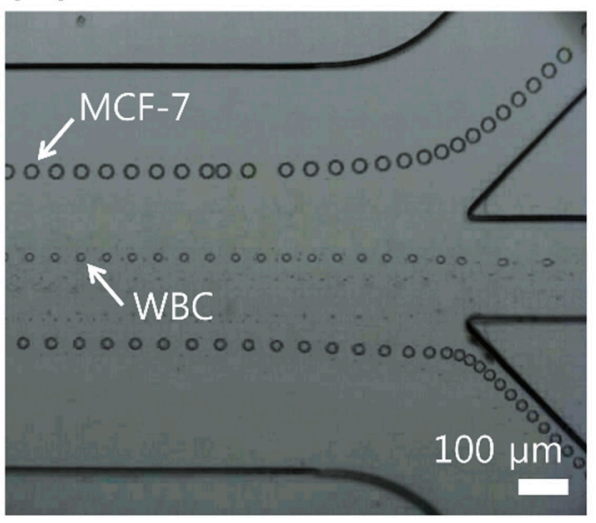

(d) MCF-7
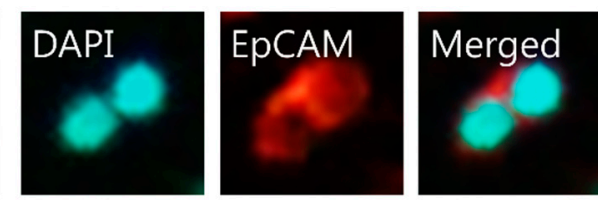

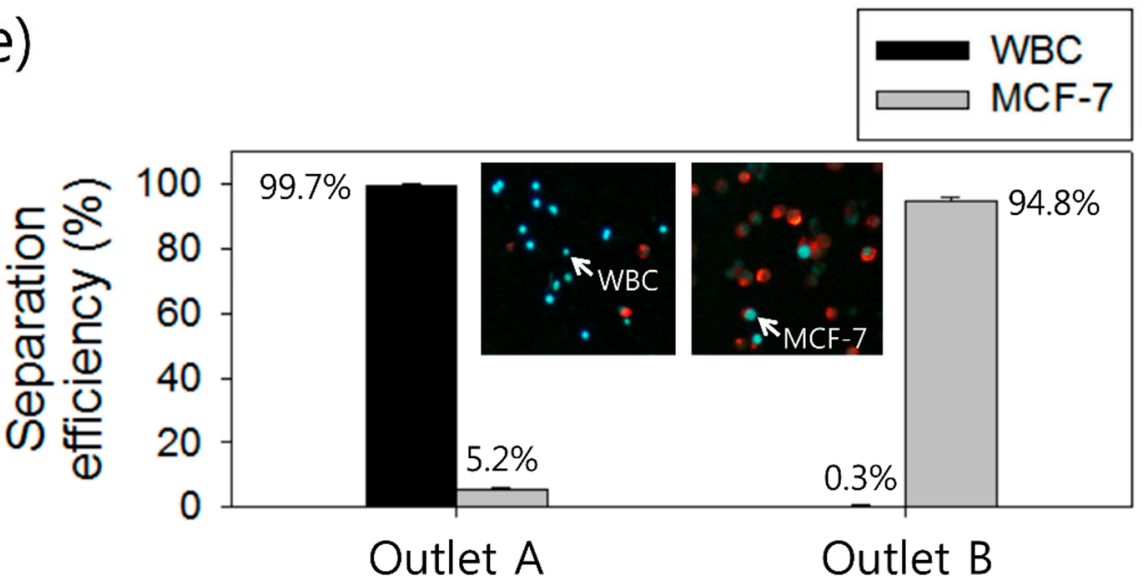

Figure 4. Cell separation of MCF-7 cells and WBCs at the flow rate of $500 \mu \mathrm{L} / \mathrm{min}$ using $0.2 \%$ HA solution. (a) At the inlet, both cells were randomly injected into the microchannel. (b) MCF-7 cells and WBCs were separated into two different streams along the center (WBCs) and off-center (MCF-7 cells). To identify (c) WBCs and (d) MCF-7 cells, fluorescent images and merged images were compared after staining with EpCAM and DAPI (4',6-DiAmidino-2-PhenylIndole). (e) Separation efficiency at each outlet by using the collected sample after the separation process. Inset figures show the fluorescent images of cells collected at outlets A and B, respectively, after the separation process.

Figure 4c,d shows the fluorescent images of MCF-7 cells and WBCs after staining using DAPI $\left(4^{\prime}, 6-\right.$ DiAmidino-2-PhenylIndole) and EpCAM, respectively. EpCAM-phycoerythrin (PE (Phycoerythrin); red) was used as a surface marker for MCF-7 cells and a nuclear stain (DAPI; blue) was used to determine both MCF-7 cells and WBCs. Here, WBCs are negative to EpCAM. As a quantitative analysis of the device capability, separation efficiency was used, which can be defined as the ratio of the number 
of target cells at the target outlet to the total number of cells found at both outlets. As shown in Figure $4 \mathrm{e}, 99.7 \%$ of WBCs were collected at outlet A, while $94.8 \%$ of MCF-7 cells were collected at outlet B. This may be due to the wide size distribution of MCF-7 cells. The purity is defined as the ratio of the number of target cells to the total number of cells collected at the target outlet. The purity of MCF-7 cells collected at outlet B was approximately $98 \%$. Inset figures show the fluorescent images of stained cells at outlet A and B collected after the separation. After the separation process, blue fluorescent cells were found in the samples collected from both outlets A and B, while only red fluorescent MCF-7 cells were collected from outlet B. After the separation process, cell viability was validated by the lactate dehydrogenase (LDH) assay, and no significant damage was observed in comparison with the cells before the separation process (Figure S3).

The breast cancer cells used for the current separation process are cultured MCF-7 cells (mean \pm $\mathrm{SD}=23.1 \pm 3.9$ ). The size distribution of MCF-7 cells and WBCs overlapped between 14 and $18 \mu \mathrm{m}$ in diameter, in which $26 \%$ of WBCs and $7 \%$ of MCF-7 cells were included. Therefore, approximately $5.2 \%$ of MCF-7 cells were collected at outlet A along with WBCs, as shown in Figure 4e. In actual clinical samples from cancer patients, the size overlap of CTCs and WBCs can be even greater due to the cell heterogeneity [5]. To address the limitation of size overlap, microbeads that are coated with capture agent anti-EpCAM can be used to amplify the size difference between tumor cells and other blood cells for high-efficiency size-dependent separation in our proposed device [50].

The device throughput can be further enhanced to be greater than $500 \mu \mathrm{L} / \mathrm{min}$ by using a rigid plastic-based microfluidic device to address the present limitation of deformation of the PDMS microchannel at high flow rates. Microfluidic fittings and adapters can also be used for leak-tight connections. Moreover, because our device is a simple straight channel with a single inlet without any sheath flows, ultra-high throughput CTC separation can be achieved by stacking or multiplexing the devices $[24,51,52]$. In addition, compressed pneumatic pressure can be conveniently used for flow generation, negating the use of precise flow control system with external power source [27].

\section{Conclusions}

In summary, we described a slit microchannel with low AR for a sheathless, high-throughput cell separation device using a viscoelastic fluid. Polystyrene particles with different sizes of 6,13 , and $27 \mu \mathrm{m}$ were used to evaluate the flow rate- and size-dependent flow characteristics in viscoelastic fluids with various concentrations $(0.1 \%, 0.2 \%$, and $0.3 \%)$. In $0.2 \%$ HA solution, particles smaller than $13 \mu \mathrm{m}(\beta \leqq 0.26)$ were tightly focused at the center of the microchannel, while $27 \mu \mathrm{m}$ particles $(\beta=0.54)$ were patterned into two fluorescent streams. Therefore, 13 and $27 \mu \mathrm{m}$ particles in $0.2 \%$ HA solution can be separated at $500 \mu \mathrm{L} / \mathrm{min}$, which was the optimized condition for CTC separation from WBCs. MCF-7 cells were finally separated with a $94.8 \%$ separation efficiency and $98 \%$ purity. Our slit microchannel device, therefore, enables the high-throughput separation process of extremely rare disease-related cells from a heterogeneous biological mixture sample.

Supplementary Materials: The following are available online at http://www.mdpi.com/2072-666X/10/7/0462/s1. Figure S1: Flow characteristics of 6, 13 and $27 \mu \mathrm{m}$ particles in PBS and 0.3\% HA solution, respectively, depending on the flow rates. Figure S2: Initial size distribution of mixed sample of MCF-7 cells and leukocytes. Figure S3: The lactate dehydrogenase (LDH) assay that assess LDH released by MCF-7 cells before and after the separation process. After the separation in the viscoelastic fluid, no significant damage was found compared to the cells before the separation process (n.s. = not significant based on Student T-test). Video S1: Separation of MCF-7 cells from WBCs at $500 \mu \mathrm{L} / \mathrm{min}$ at the outlet.

Author Contributions: Conceptualization, J.N.; methodology, J.N.; validation, J.N., H.L., and S.M.B.; formal analysis, J.N. and H.L.; investigation, H.L., and S.M.B.; resources, M.H.H. and D.H.L.; data curation, J.N. and H.L.; writing-original draft preparation, J.N. and H.L.; writing—review and editing, J.N.; visualization, J.N., H.L., and S.M.B.; supervision, J.N. and H.C.; project administration, J.N. and H.C.; funding acquisition, J.N. and H.C.

Funding: This research was funded by the Ministry of Education, grant number 2017R1D1A1A09000962.

Acknowledgments: This research was supported by the Basic Science Research Program through the National Research Foundation of Korea (NRF) funded by the Ministry of Education (2017R1D1A1A09000962). 
Conflicts of Interest: The authors declare no conflict of interest.

\section{References}

1. Pantel, K.; Alix-Panabières, C. Circulating tumour cells in cancer patients: Challenges and perspectives. Trends Mol. Med. 2010, 16, 398-406. [CrossRef] [PubMed]

2. Cristofanilli, M.; Budd, G.T.; Ellis, M.J.; Stopeck, A.; Matera, J.; Miller, M.C.; Reuben, J.M.; Doyle, G.V.; Allard, W.J.; Terstappen, L.W.M.M.; et al. Circulating Tumor Cells, Disease Progression, and Survival in Metastatic Breast Cancer. N. Engl. J. Med. 2004, 351, 781-791. [CrossRef] [PubMed]

3. Alix-Panabieres, C.; Pantel, K. Clinical Applications of Circulating Tumor Cells and Circulating Tumor DNA as Liquid Biopsy. Cancer Discov. 2016, 6, 479-491. [CrossRef] [PubMed]

4. Hou, J.M.; Krebs, M.; Ward, T.; Morris, K.; Sloane, R.; Blackhall, F.; Dive, C. Circulating Tumor Cells, Enumeration and Beyond. Cancers 2010, 2, 1236-1250. [CrossRef]

5. Song, Y.L.; Tian, T.; Shi, Y.Z.; Liu, W.L.; Zou, Y.; Khajvand, T.; Wang, S.L.; Zhu, Z.; Yang, C.Y. Enrichment and single-cell analysis of circulating tumor cells. Chem. Sci. 2017, 8, 1736-1751. [CrossRef] [PubMed]

6. Shields, C.W., IV; Reyes, C.D.; Lopez, G.P. Microfluidic cell sorting: A review of the advances in the separation of cells from debulking to rare cell isolation. Lab Chip 2015, 15, 1230-1249. [CrossRef] [PubMed]

7. Cho, H.; Kim, J.; Song, H.; Shon, K.Y.; Han, K.H. Microfluidic technologies for circulating tumor cell isolation. Analyst 2018, 143, 2936-2970. [CrossRef]

8. Thege, F.I.; Lannin, T.B.; Saha, T.N.; Tsai, S.; Kochman, M.L.; Hollingsworth, M.A.; Rhim, A.D.; Kirby, B.J. Microfluidic immunocapture of circulating pancreatic cells using parallel EpCAM and MUC1 capture: Characterization, optimization and downstream analysis. Lab Chip 2014, 14, 1775-1784. [CrossRef]

9. Yang, J.; Weinberg, R.A. Epithelial-mesenchymal transition: At the crossroads of development and tumor metastasis. Dev. Cell 2008, 14, 818-829. [CrossRef]

10. Gascoyne, P.R.; Noshari, J.; Anderson, T.J.; Becker, F.F. Isolation of rare cells from cell mixtures by dielectrophoresis. Electrophoresis 2009, 30, 1388-1398. [CrossRef]

11. Shim, S.; Stemke-Hale, K.; Tsimberidou, A.M.; Noshari, J.; Anderson, T.E.; Gascoyne, P.R. Dielectrophoresis has broad applicability to marker-free isolation of tumor cells from blood by microfluidic systems. Biomicrofluidics 2013, 7, 11807. [CrossRef] [PubMed]

12. Augustsson, P.; Magnusson, C.; Nordin, M.; Lilja, H.; Laurell, T. Microfluidic, Label-Free Enrichment of Prostate Cancer Cells in Blood Based on Acoustophoresis. Anal. Chem. 2012, 84, 7954-7962. [CrossRef] [PubMed]

13. Antfolk, M.; Kim, S.H.; Koizumi, S.; Fujii, T.; Laurell, T. Label-free single-cell separation and imaging of cancer cells using an integrated microfluidic system. Sci. Rep. 2017, 7, 46507. [CrossRef] [PubMed]

14. Ding, X.; Peng, Z.; Lin, S.C.S.; Geri, M.; Li, S.; Li, P.; Chen, Y.; Dao, M.; Suresh, S.; Huang, T.J. Cell separation using tilted-angle standing surface acoustic waves. Proc. Natl. Acad. Sci. USA 2014, 111, 12992-12997. [CrossRef] [PubMed]

15. Li, P.; Mao, Z.; Peng, Z.; Zhou, L.; Chen, Y.; Huang, P.H.; Truica, C.I.; Drabick, J.J.; El-Deiry, W.S.; Dao, M.; et al. Acoustic separation of circulating tumor cells. Proc. Natl. Acad. Sci. USA 2015, 112, 4970-4975. [CrossRef] [PubMed]

16. Hosokawa, M.; Hayata, T.; Fukuda, Y.; Arakaki, A.; Yoshino, T.; Tanaka, T.; Matsunaga, T. Size-Selective Microcavity Array for Rapid and Efficient Detection of Circulating Tumor Cells. Anal. Chem. 2010, 82, 6629-6635. [CrossRef]

17. Zheng, S.; Lin, H.K.; Lu, B.; Williams, A.; Datar, R.; Cote, R.J.; Tai, Y.C. 3D microfilter device for viable circulating tumor cell (CTC) enrichment from blood. Biomed. Microdevices 2011, 13, 203-213. [CrossRef] [PubMed]

18. Xu, L.; Mao, X.; Imrali, A.; Syed, F.; Mutsvangwa, K.; Berney, D.; Cathcart, P.; Hines, J.; Shamash, J.; Lu, Y.J. Optimization and Evaluation of a Novel Size Based Circulating Tumor Cell Isolation System. PLoS ONE 2015, 10, e0138032. [CrossRef]

19. Tan, S.J.; Lakshmi, R.L.; Chen, P.; Lim, W.T.; Yobas, L.; Lim, C.T. Versatile label free biochip for the detection of circulating tumor cells from peripheral blood in cancer patients. Biosens. Bioelectron. 2010, 26, 1701-1705. [CrossRef]

20. Loutherback, K.; D'Silva, J.; Liu, L.; Wu, A.; Austin, R.; Sturm, J.C. Deterministic separation of cancer cells from blood at $10 \mathrm{~mL} / \mathrm{min}$. AIP Adv. 2012, 2, 42107. [CrossRef] 
21. Warkiani, M.E.; Khoo, B.L.; Wu, L.; Tay, A.K.P.; Bhagat, A.A.S.; Han, J.; Lim, C.T. Ultra-fast, label-free isolation of circulating tumor cells from blood using spiral microfluidics. Nat. Protoc. 2016, 11, 134-148. [CrossRef] [PubMed]

22. Kim, T.H.; Yoon, H.J.; Stella, P.; Nagrath, S. Cascaded spiral microfluidic device for deterministic and high purity continuous separation of circulating tumor cells. Biomicrofluidics 2014, 8, 064117. [CrossRef] [PubMed]

23. Sollier, E.; Go, D.E.; Che, J.; Gossett, D.R.; O’Byrne, S.; Weaver, W.M.; Kummer, N.; Rettig, M.; Goldman, J.; Nickols, N.; et al. Size-selective collection of circulating tumor cells using Vortex technology. Lab Chip 2014, 14, 63-77. [CrossRef] [PubMed]

24. Che, J.; Yu, V.; Dhar, M.; Renier, C.; Matsumoto, M.; Heirich, K.; Garon, E.B.; Goldman, J.; Rao, J.; Sledge, G.W.; et al. Classification of large circulating tumor cells isolated with ultra-high throughput microfluidic Vortex technology. Oncotarget 2016, 7, 12748-12760. [CrossRef] [PubMed]

25. Lu, X.; Liu, C.; Hu, G.; Xuan, X. Particle manipulations in non-Newtonian microfluidics: A review. J. Colloid Interface Sci. 2017, 500, 182-201. [CrossRef] [PubMed]

26. Leshansky, A.M.; Bransky, A.; Korin, N.; Dinnar, U. Tunable Nonlinear Viscoelastic "Focusing" in a Microfluidic Device. Phys. Rev. Lett. 2007, 98, 234501. [CrossRef] [PubMed]

27. Nam, J.; Jang, W.S.; Lim, C.S. Non-electrical powered continuous cell concentration for enumeration of residual white blood cells in WBC-depleted blood using a viscoelastic fluid. Talanta 2019, 197, 12-19. [CrossRef]

28. Ahn, S.W.; Lee, S.S.; Lee, S.J.; Kim, J.M. Microfluidic particle separator utilizing sheathless elasto-inertial focusing. Chem. Eng. Sci. 2015, 126, 237-243. [CrossRef]

29. Kim, B.; Kim, J. Elasto-inertial particle focusing under the viscoelastic flow of DNA solution in a square channel. Biomicrofluidics 2016, 10, 024111. [CrossRef]

30. Nam, J.; Lim, H.; Kim, D.; Jung, H.; Shin, S. Continuous separation of microparticles in a microfluidic channel via the elasto-inertial effect of non-Newtonian fluid. Lab Chip 2012, 12, 1347-1354. [CrossRef]

31. Nam, J.; Namgung, B.; Lim, C.T.; Bae, J.E.; Leo, H.L.; Cho, K.S.; Kim, S. Microfluidic device for sheathless particle focusing and separation using a viscoelastic fluid. J. Chromatogr. A 2015, 1406, 244-250. [CrossRef] [PubMed]

32. Nam, J.; Shin, Y.; Tan, J.K.S.; Lim, Y.B.; Lim, C.T.; Kim, S. High-throughput malaria parasite separation using a viscoelastic fluid for ultrasensitive PCR detection. Lab Chip 2016, 16, 2086-2092. [CrossRef] [PubMed]

33. Nam, J.; Tan, J.K.S.; Khoo, B.L.; Namgung, B.; Leo, H.L.; Lim, C.T.; Kim, S. Hybrid capillary-inserted microfluidic device for sheathless particle focusing and separation in viscoelastic flow. Biomicrofluidics 2015, 9, 064117. [CrossRef] [PubMed]

34. Liu, C.; Guo, J.; Tian, F.; Yang, N.; Yan, F.; Ding, Y.; Wei, J.; Hu, G.; Nie, G.; Sun, J. Field-Free Isolation of Exosomes from Extracellular Vesicles by Microfluidic Viscoelastic Flows. ACS Nano 2017, 11, 6968-6976. [CrossRef] [PubMed]

35. Faridi, M.A.; Ramachandraiah, H.; Banerjee, I.; Ardabili, S.; Zelenin, S.; Russom, A. Elasto-inertial microfluidics for bacteria separation from whole blood for sepsis diagnostics. J. Nanobiotechnol. 2017, 15, 3. [CrossRef] [PubMed]

36. Tian, F.; Cai, L.; Chang, J.; Li, S.; Liu, C.; Li, T.; Sun, J. Label-free isolation of rare tumor cells from untreated whole blood by interfacial viscoelastic microfluidics. Lab Chip 2018, 18, 3436-3445. [CrossRef] [PubMed]

37. Liu, C.; Xue, C.; Chen, X.; Shan, L.; Tian, Y.; Hu, G. Size-Based Separation of Particles and Cells Utilizing Viscoelastic Effects in Straight Microchannels. Anal. Chem. 2015, 87, 6041-6048. [CrossRef] [PubMed]

38. Li, D.; Lu, X.; Xuan, X. Viscoelastic Separation of Particles by Size in Straight Rectangular Microchannels: A Parametric Study for a Refined Understanding. Anal. Chem. 2016, 88, 12303-12309. [CrossRef]

39. Nam, J.; Jang, W.S.; Hong, D.H.; Lim, C.S. Viscoelastic Separation and Concentration of Fungi from Blood for Highly Sensitive Molecular Diagnostics. Sci. Rep. 2019, 9, 3067. [CrossRef]

40. Lim, E.J.; Ober, T.J.; Edd, J.F.; Desai, S.P.; Heal, D.; Bong, K.W.; Doyle, P.S.; McKinley, G.H.; Toner, M. Inertio-elastic focusing of bioparticles in microchannels at high throughput. Nat. Commun. 2014, 5, 4120. [CrossRef]

41. Seo, K.W.; Byeon, H.J.; Huh, H.K.; Lee, S.J. Particle migration and single-line particle focusing in microscale pipe flow of viscoelastic fluids. RSC Adv. 2014, 4, 3512-3520. [CrossRef]

42. Tehrani, M. An experimental study of particle migration in pipe flow of viscoelastic fluids. J. Rheol. 1996, 40, 1057-1077. [CrossRef] 
43. Aceto, N.; Bardia, A.; Miyamoto, D.T.; Donaldson, M.C.; Wittner, B.S.; Spencer, J.A.; Yu, M.; Pely, A.; Engstrom, A.; Zhu, H.; et al. Circulating tumor cell clusters are oligoclonal precursors of breast cancer metastasis. Cell 2014, 158, 1110-1122. [CrossRef] [PubMed]

44. Rostami, P.; Kashaninejad, N.; Moshksayan, K.; Saidi, M.; Firoozabadi, B.; Nguyen, N. Novel approaches in cancer management with circulating tumor cell clusters. J. Sci. Adv. Mater. Dev. 2019. [CrossRef]

45. Zhou, Y.; Basu, S.; Wohlfahrt, K.J.; Lee, S.F.; Klenerman, D.; Laue, E.D.; Seshia, A.A. A microfluidic platform for trapping, releasing and super-resolution imaging of single cells. Sens. Actuators B Chem. 2016, 232, 680-691. [CrossRef] [PubMed]

46. Geislinger, T.M.; Franke, T. Sorting of circulating tumor cells (MV3-melanoma) and red blood cells using non-inertial lift. Biomicrofluidics 2013, 7, 044120. [CrossRef]

47. Zhou, J.; Giridhar, P.V.; Kasper, S.; Papautsky, I. Modulation of rotation-induced lift force for cell filtration in a low aspect ratio microchannel. Biomicrofluidics 2014, 8, 044112. [CrossRef]

48. Dhahir, S.; Walters, K. On Non-Newtonian Flow Past a Cylinder in a Confined Flow. J. Rheol. 1989, $33,781$. [CrossRef]

49. Huang, P.Y.; Joseph, D.D. Effects of shear thinning on migration of neutrally buoyant particles in pressure driven flow of Newtonian and viscoelastic fluids. J. Non-Newtonian Fluid Mech. 2000, 90, 159-185. [CrossRef]

50. Liu, H.; Ao, Z.; Cai, B.; Shu, X.; Chen, K.; Rao, L.; Luo, C.; Wang, F.B.; Liu, W.; Bondesson, M.; et al. Size-amplified acoustofluidic separation of circulating tumor cells with removable microbeads. Nano Futures 2018, 2, 025004. [CrossRef]

51. Khoo, B.L.; Warkiani, M.E.; Tan, D.S.W.; Bhagat, A.A.S.; Irwin, D.; Lau, D.P.; Lim, A.S.T.; Lim, K.H.; Krisna, S.S.; Lim, W.T.; et al. Clinical Validation of an Ultra High-Throughput Spiral Microfluidics for the Detection and Enrichment of Viable Circulating Tumor Cells. PLoS ONE 2014, 9, e99409. [CrossRef] [PubMed]

52. Warkiani, M.E.; Khoo, B.L.; Tan, D.S.W.; Bhagat, A.A.S.; Lim, W.T.; Yap, Y.S.; Lee, S.C.; Soo, R.A.; Han, J.; Lim, C.T. An ultra-high-throughput spiral microfluidic biochip for the enrichment of circulating tumor cells. Analyst 2014, 139, 3245-3255. [CrossRef] [PubMed]

(C) 2019 by the authors. Licensee MDPI, Basel, Switzerland. This article is an open access article distributed under the terms and conditions of the Creative Commons Attribution (CC BY) license (http://creativecommons.org/licenses/by/4.0/). 